\title{
Pesticide Influence on the Desmid Flora of a Reservoir in an Agricultural Region at Campo Verde, Mato Grosso, Brazil
}

\author{
Juliana Kawanishi Braga ${ }^{1}$, Edna Lopes Hardoim1, \\ Eliana Freire Gaspar de Carvalho Dores ${ }^{2}$, Charles William Heckman' \\ ${ }^{1}$ LATEMAS (Laboratory of Taxonomy and Ecology of Aquatic and Symbionts Microrganism), \\ Instituto de Biociências, Universidade Federal de Mato Grosso, Cuiabá, Brazil \\ ${ }^{2}$ LARB (Laboratory of Analysis of Biocide Residues), Instituto de Ciências Exatas e da Terra, \\ Universidade Federal de Mato Grosso, Cuiabá, Brazil

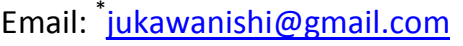

Received 18 July 2014; revised 16 August 2014; accepted 3 September 2014

Copyright (C) 2014 by authors and Scientific Research Publishing Inc.

This work is licensed under the Creative Commons Attribution International License (CC BY). http://creativecommons.org/licenses/by/4.0/

c) (i) Open Access

\begin{abstract}
The objective of the research was to investigate the influence of pesticides on the desmid flora. Five series of samples were taken between July 5, 2005, and April 6, 2006, for analysis of pesticide content and algal community structure in the São Lourenço River springs on the Pirassununga Ranch, Campo Verde, Mato Grosso. The greatest amounts of pesticides were detected in July, when the abundance of algae was also greatest. Positive correlations were determined between the concentrations of endosulfan $(r=0.94 ; p=0.051)$, cyhalothrin $(r=0.96 ; p=0.037)$ and endrin $(r=$ 0.96; $p=0.037$ ) and the biomass of desmids. Insecticides, such as endosulfan, inhibit the activity of ATPase, contributing considerably to the mortality of the biota, since ATP is of fundamental importance in the energy metabolism of all organisms. This suggests that the pesticides promote algal growth both by removing the small herbivores that feed on the algae and increasing the release of inorganic nutrients from decomposing animals in the water. Algae were least abundance in January, possibly due to the presence of the herbicide atrazine $(r=-0.63 ; p>0.05)$.
\end{abstract}

\section{Keywords}

Algal Abundance, Atrazine, Seasonality, Springs

\footnotetext{
*Corresponding author.
} 


\section{Introduction}

One of the most important tasks of researchers in applied limnology has been to detect and estimate the degree of harm done by each of the great variety of pollutants entering surface waters due to human activities.

Nowadays, more and more concern is shown about the possibility of adverse effects of pesticides on human health and natural ecosystems. Agricultural use of herbicides remains popular, however, because of the direct benefits their application provides, such as increased agricultural yields and reduction of labor [1].

The concentrations of the majority of pesticides detected in water remain generally low, due to their low solubility and dilution. However, even when their concentrations are low, the pesticides can have harmful consequences for various aquatic species because their harmful ingredients bioconcentrate within the organisms to as much as 1000 times the concentration in the ambient water [2].

Herbicides can affect the structure and function of aquatic communities by altering species composition of the alga flora. Little is known, however, about the toxicity of herbicides to freshwater green algae [3]. Because of the great importance of algae as nutritional bases of local food webs, this study was undertaken to record obvious impacts of the pesticides used in local agriculture on the algal species that were abundant in the water of an impounded stream leading from a spring in the Brazilian State of Mato Grosso, which is one of the sources of the São Lourenço River. No ecological studies have been conducted in this region, which has been extensively modified for agriculture in recent years.

Surface waters located in intensive agricultural areas are obviously more vulnerable to pesticide contamination. The efficacy of the pesticides is reflected by high levels of acute toxicity on target and non-target organisms [4].

Nevertheless, only a few studies have been conducted on the ecotoxicological effects of herbicidal compounds on aquatic photosynthetic organisms, including higher plants [5] [6], symbiotic algae [7] , and microalgae [8]. It has recently been concluded that environmentally relevant concentrations observed in the field could be inhibiting the growth and activity of the photosynthetic organisms [9].

This study was undertaken to chemically analyze water samples taken during different seasonal periods and determine the amounts of the pesticides commonly used on the cultivated fields nearby and assess their influence on the desmid flora in the water at the time samples were taken. The results of the chemical analyses and investigations of the algal fauna could then be used to complete a general seasonal evaluation of the water chemistry and microflora dynamics in the streams and identify possible effects of each pesticide on the algae present. In this way, specific problems that require more detailed investigation in future laboratory studies could be identified.

Initial sampling revealed that the predominant group of green algae at the sampling sites were desmids. This study therefore provides additional information on the distribution and habitat requirements of species in the family Desmidiaceae, which is well represented in the tropical water bodies of Mato Grosso.

Some research methods depend upon the presence or absence of specific biotic communities or indicator organisms to recognize pristine conditions or determine the extent of pollution effects. However, changes in the structure of the biotic community are not always indicative of specific changes in the ecosystem. In multifactorial systems, any one of many conditions may be responsible for changes. The present investigation is therefore meant to focus attention on effects that will require special study.

\section{Objectives}

\subsection{General Goals}

The management of catchment areas is complicated when a comprehensive infrastructural network is lacking and established techniques are not employed. The result of these inadequacies is the failure to eliminate agricultural chemical residues from the system, which exposes the environment to their cumulative effects. The data obtained during this study are meant to assist public officials, and especially management and regulatory agencies, to plan and manage the hydrological resources.

\subsection{Specific Goals}

This study was undertaken to test the hypothesis that pesticides contaminate an impoundment near the source of 
the São Lourenço River in Campo Verde, a municipal district in the state of Mato Grosso, and to determine the alterations in the algal assemblages these residues produce.

The study also elucidates the interactions between microorganisms and their environment in hydrographic basins located in agricultural regions, verifies pesticide contamination of surface waters near cultivated fields in the southern part of the state, and evaluates the effects of the pesticide residues on populations of algae in the surface waters of the study area.

\section{Material and Methods}

\subsection{Study Area}

The municipal district of Campo Verde is located in the southeastern part of Mato Grosso, Brazil, about $190 \mathrm{~km}$ east of Cuiabá, the capital of Mato Grosso State, at an elevation of $736 \mathrm{~m}$ above sea level, according to the WGS84 system. It covers an area of $4744.5 \mathrm{~km}^{2}$. Campo Verde has a tropical climate with temperatures usually varying between $18^{\circ} \mathrm{C}$ and $24^{\circ} \mathrm{C}$ but with extreme absolute minimum and maximum temperatures between $10^{\circ} \mathrm{C}$ and $34^{\circ} \mathrm{C}$. Monthly precipitation varies between 9 and $225 \mathrm{~mm}$, with a rainy season lasting from December to May. The vegetation type is predominantly cerrado biome, a dry forest ecosytem, which covers about $97 \%$ of the area. The remaining 3\% is covered by typical forest.

The Pirassununga Ranch (GPS 15 37'19.4"S and 55 10'29.6"W) is located at km 389 along Highway BR70, about $6 \mathrm{~km}$ from the center of the town Campo Verde, Mato Grosso (Figure 1). On this ranch, there is an impoundment which is currently one of the sources of the São Lourenço River, the drainage area of which is in the State of Mato Grosso. This river passes the city of Dom Aquino and discharges into the Pantanal. Springs in the region are fed by water from aquifers that are little influenced over the short term by local rainfall, minimizing the effects of daily weather on the water flow.

In Campo Verde, where one of its sources is located, major erosion carries thousands of tons of sand to the bottom of the river. A few kilometers from the source, near the city of Jaciara, the São Lourenço River already shows major changes. A patchwork of sugar cane and soy bean fields interspersed with pastures for cattle come dangerously close to the river banks. These provide examples of how little people care for the river which gives its name to one of the most prosperous regions of the state, the São Lourenço Valley.

\subsection{Methodological Procedures in the Field and in the Laboratory}

\subsubsection{Methods Used in the Field}

Five expeditions to the field provided the data for this study. During these expeditions in July, August, and October, 2005, and in January and April, 2006, samples of the algae communities were taken from one of the sources of the São Lourenço River, impounded on the Pirassununga Ranch.

For the analysis of phytoplankton, samples were collected using a plankton net with $38 \mu \mathrm{m}$ pores, through which $200 \mathrm{l}$ of each sample were filtered. The material collected was fixed in glass flasks and preserved in a transeau solution diluted 1:1, according to the method of [10].

The following limnological variables were recorded: 1 ) water temperatures in ${ }^{\circ} \mathrm{C}$ and oxygen concentration in $\mathrm{mg} / \mathrm{L}, 2$ ) air temperature in ${ }^{\circ} \mathrm{C}$, 3) $\mathrm{pH}$, and 4) electrical conductivity of the water in $\mu \cdot \mathrm{S} \cdot \mathrm{cm}^{-1}$.

\subsubsection{Laboratory-Analyses of the Biota and the Pesticides}

The Laboratory of Taxonomy and Ecology of Aquatic and Symbiontic Microrganism (LATEMAS) has developed an unpublished volume of protocols, which is routinely employed earlier for analyzing the diversity of the microbiota in samples from inland water bodies. Following these protocols, 25 aliquots of each sample were placed under cover slips on slides and examined under a light microscope. The microorganisms were counted using phase contrast and applying the continuous field technique with an ocular counting grid. Curves were plotted for the number of species against the area of the slide containing $1 \mathrm{~mm}$ of sample, according to [11].

To analyze the pesticides in the water bodies, $500 \mathrm{ml}$ of each water sample were passed through glass fiber filters, after which the $\mathrm{pH}$ was adjusted to between 6.5 and 7.5. Each sample was then passed through a cartridge containing $1 \mathrm{~g}$ of solid phase C-18 using a vacuum extraction system. The cartridges had been previously condi- 


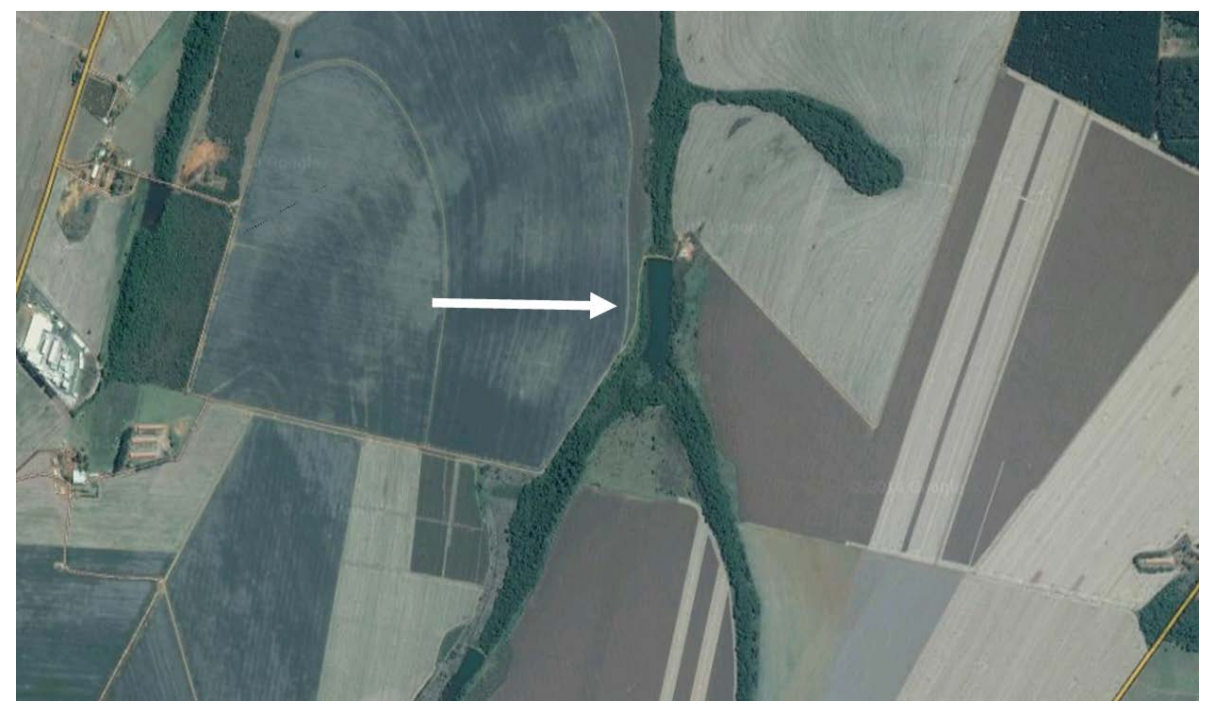

Figure 1. The Pirassununga Ranch (Campo Verde, Mato Grosso, Brazil) and the collection point (dam) with the arrow indication. Source: Google Earth.

tioned by passing $10 \mathrm{ml}$ of methanol and $10 \mathrm{ml}$ of deionized water through the adsorbent. After percolation of the sample, the cartridge was centrifuged for five minutes and then eluted with $10 \mathrm{ml}$ of ethyl acetate, $10 \mathrm{ml}$ of a 7:3 hexane-ethyl acetate mixture, and $5 \mathrm{ml}$ of hexane, which were poured into Erlenmeyer flasks through a glass funnel containing $2 \mathrm{~g}$ of anhydrous sodium sulfate on glass wool. Then, $5 \mathrm{ml}$ of hexane was added through the funnel containing the sodium sulfate. To the eluate in the flask, 5 drops of toluene were added, and the mixture was concentrated in a rotary evaporator at $45^{\circ} \mathrm{C}, 270 \mathrm{mbar}$, and a rotation speed of $90 \mathrm{rpm}$, until near dryness. The concentrate was redissolved in toluene, and $50 \mu \mathrm{g}$ of $\alpha-\mathrm{HCH}$ (hexachlorocyclohexane) was added as an internal standard for analysis in a gas chromatograph with mass spectrometer detection [12].

\subsubsection{Climatological Data}

The climatological data for each sampling day were obtained courtesy of the Ninth Meteorological District of the Brazilian Ministry of Agriculture (Ministério da Agricultura, Pecuaria e Abastecimento). Therefore, it must be mentioned that the weather station located closest to the sampling area was situated at São Vicente, Mato Grosso, about $60 \mathrm{~km}$ far from the study area, where the terrain elevation is $880 \mathrm{~m}$ above sea level, and the barometric elevation $(\mathrm{Hb})$ is $800 \mathrm{~m}$.

\section{Results and Discussion}

\subsection{Characterization of the Sampling Area}

The strip of land between the shores of the impoundment and the borders of the cultivated fields is about $60 \mathrm{~m}$ wide and used as pasture. The sampling area is located a distance of about $100 \mathrm{~m}$ from a spring that is one of the sources of the São Lourenço River. This $100 \mathrm{~m}$ from the spring to the impoundment is not covered with any kind of vegetation that could form a buffer zone to reduce the visible anthropogenic influence in the region.

\subsubsection{Physical and Chemical Data}

Changes in phytoplankton community dynamics reflect physical, chemical, and biological changes within the water body.

Surface waters can have a pH between 4 and 9. Sometimes, they become alkaline due to the presence of carbonates and bicarbonates. Microrganisms grow well within the range of 6.5 and 8.5 [13]. The limnological data obtained indicate that at the moment of collection, the $\mathrm{pH}$ of the water sampled from the impoundment varied from 5.55 in the fourth sample to 6.44 in the third. These samples were taken during the rainy season and dry season, respectively (Table 1 ).

The concentration of dissolved oxygen (OD) at the location of the study varied from 3.3 to $5.8 \mathrm{mg} / \mathrm{L}$, values 
Table 1. Physical and chemical data from the impoundment during the study period.

\begin{tabular}{cccccc}
\hline & Sample 01 & Sample 02 & Sample 03 & Sample 04 & Sample 05 \\
\hline Sampling date & Jul. 28, 2005 & Aug. 30, 2005 & Oct. 7, 2006 & Jan. 27, 2006 & Apr. 13, 2006 \\
pH & 5.7 & 6.1 & 6.44 & 5.55 & 5.84 \\
Oxygen concentration $(\mathrm{mg} / \mathrm{l})$ & 4.2 & 4.2 & 3.3 & 3.7 & 5.82 \\
Water temperature $\left({ }^{\circ} \mathrm{C}\right)$ & 25.2 & 30 & $*$ & 24.5 & 29 \\
Air temperature $\left({ }^{\circ} \mathrm{C}\right)$ & 29.7 & 39 & 27 & 25 & 29.5 \\
Conductivity $(\mu \mathrm{S} / \mathrm{cm})$ & $*$ & 22.9 & 26.5 & 25.9 & 26.3 \\
\hline
\end{tabular}

* missing data.

obtained during the months of October and April, respectively, always at about 10:00 a.m. Oxygen concentrations can be assumed to have been low due to a major input of organic material into the water course, which istypical in agricultural regions, especially those receiving run-off during rainy periods. This input of organic material can initiate a reduction in the amount of dissolved oxygen, which is consumed to decompose the oxidizable compounds. On the other hand, the abundance of microalgae observed at that location accounts for the restoration of the dissolved oxygen, which demonstrates the importance of these organisms within the system.

According to [14], the dissolved oxygen in each sample may not be below $6 \mathrm{mg} / \mathrm{L}$, and the $\mathrm{pH}$ must be in the range from 6.0 to 9.0. The results of this study verify that the ambient conditions determined did not meet the requirements [14], permitting it to be inferred that the anthropogenic impact in this agricultural environment directly or indirectly affects the quality of the hydrological resources [15].

In Table 1, it can be seen that the greatest electrical conductivity, $26.5 \mu \mathrm{S} \cdot \mathrm{cm}$, was recorded during October. However, the data recorded during the study period did not reveal a seasonal pattern for the conductivity, which confirms the findings of other authors [16]-[18], based on studies of other water courses in the State of Mato Grosso, since the values obtained for both periods appear similar.

It should be emphasized that, according to [15], various organic substances can ionize and thereby contribute to elevating the electrical conductivity of the water. According to the same author, rain leaches nutrients and other chemical compounds from the catchment area, increasing the concentrations of dissolved ions in the water and thereby also the capacity of the water to conduct electricity. Considering the declivity of the slope towards the river in the area, this leaching process can explain the seasonal elevation of the electrical conductivity determined during this study. The basic characteristic of tropical lakes and impoundments is a temperature that remains more or less uniform during the course of the year, as observed in Table 1.

In tropical regions, the temperature does not have a very significant effect on the temporal variations in the phytoplankton, especially in comparison to lakes in the temperate zone, where the seasonal conditions are well defined. Water temperature was highest, with a mean of about $30^{\circ} \mathrm{C}$, during the dry season in the month of August, when air temperatures reach values as high as $39^{\circ} \mathrm{C}$. Analyses by Pearson correlation did not reveal a positive or a negative correlation between the abundance of phytoplankton and temperature differences in the water $(r=-0.25 ; p=0.74)$ or in its environment $(r=0.008 ; p=0.99)$, corroborating the findings of [19], who concluded that other factors are the determinants of temporal variations in the phytoplankton.

These authors demonstrated that insolation and precipitation have little influence on the variation in the algal biomass, which was also verified by the present study, although the data presented here do not permit a generalization because the set of samples is too small.

\subsubsection{Climatological Data}

According to [20], the temporal variations in the phytoplankton of tropical lakes are controlled by various factors, the most important of which are the availability of nutrients and light beneath the water surface.

In the region studied, the air temperature remained relatively constant, varying from $21.4^{\circ} \mathrm{C}$ to $25^{\circ} \mathrm{C}$, except in August, when it was near the maximum temperature of the range, $39^{\circ} \mathrm{C}$. In contrast, the relative humidity varied considerably from $67 \%$ to $95 \%$, with its peak during the fifth sampling period (Table 2).

The absence of clouds during the month of July might be thought to explain the data recorded for the abun- 
Table 2. Climatological data for the study period, recorded at Campo Verde, Mato Grosso.

\begin{tabular}{cccccc}
\hline & \multicolumn{5}{c}{ Climatological data } \\
\hline & Sample 1 & Sample 2 & Sample 3 & Sample 4 & Sample 5 \\
\hline Date & July 28, 2005 & Aug. 30, 2005 & Oct. 7, 2005 & Jan. 26, 2006 & Apr. 13, 2006 \\
Air temperature $\left({ }^{\circ} \mathrm{C}\right)$ & 24 & 25 & 31.4 & 22.4 & 21.6 \\
Tx $\left({ }^{\circ} \mathrm{C}\right)$ & 31.5 & 32.4 & 33.0 & 29.4 & 28 \\
Tn $\left({ }^{\circ} \mathrm{C}\right)$ & 19 & 22.8 & 18.1 & 20.8 & 21 \\
Relative humidity (\%) & 70 & 67 & 52 & 86 & 95 \\
Total precipitation (mm) & 0 & 0 & 205.1 & 37.4 & 15 \\
Evaporation (mm) & 7.1 & 10.4 & 2.0 & 2.6 & 1.6 \\
Cloud cover (0 a 10) & 0 & 0 & 8 & 8 & 5 \\
Visibility & 9 & 7 & 9 & 9 & 9 \\
Insolation & $*$ & 5.7 & 7.3 & 3.4 & 5.3 \\
\hline
\end{tabular}

Tx-Maximum temperature for the day; Tn-Minimum temperature for the day; ${ }^{*}$-Data are unavailable.

dance of phytoplankton. However, there was no cloud cover at all during the month of August, as well, but there were no corresponding abundance of algae, indicating that other factors were affecting the occurrence and abundance of the individual algal species recorded.

Consideration was given not only to the climatological data obtained at the time of sampling but also to the monthly median average of each variable, except precipitation, during the months each series of samples was collected jointly with INMET at Várzea Grande. Except in October, the month during which the rainy season begins, no precipitation was recorded during sampling.

The sampling series taken during that month was collected on October 7, 2005, when no precipitation was recorded. However, the total precipitation for the month was $205.1 \mathrm{~mm}$, meaning that samples considered to have been collected during the rainy season were also included in the research.

It must be pointed out that the air temperature, relative humidity, cloud cover, and visibility values shown in Table 2 are those obtained at 12 noon at INMET, Várzea Grande, which have been used as the reference data for the day.

\subsubsection{Pesticide Concentration in Water}

Even though toxic agricultural chemicals could have been responsible for a variety of chronic and acute toxic effects, the microorganisms also have the capacity for metabolizing some of these chemicals [17].

The data reflect seasonal differences. Analyses of the pesticides revealed that their greatest concentrations were encountered during July. The three kinds present during that month were endosulfan sulfate, lambda cyhalothrin and endrin. It was also determined that the greatest variation in the amounts of pesticides detected occurred during January, although these concentrations were relatively low (Table 3). A reduction in the amounts detected was observed during the rainy season, and the lowest values were encountered during the high water period. The low values probably resulted from dilution by the intensive rainfall or the low solubility of the substances in water, as reported by [21].

\subsubsection{Concentration of Pesticides in the Water}

[14] defines the maximum permissible concentrations of pesticides in the environment, including $2 \mu \mathrm{g} / \mathrm{L}$ for atrazine, $0.004 \mu \mathrm{g} / \mathrm{L}$ for endrin, $0.056 \mu \mathrm{g} / \mathrm{L}$ for endosulfan, and $10 \mu \mathrm{g} / \mathrm{L}$ for metolachlor. During this study, levels for atrazine and metolachlor remained within the limits; however, this does not guarantee their presence is not able to influence some forms of organisms or their habitats.

\subsection{Abundance of Desmids and the Concentrations of the Pesticides Encountered}

The structure of phytoplankton communities, like those of zooplankton, is determined by the growth, reproduc- 
Table 3. Concentration of pesticides $(\mu \mathrm{g} / \mathrm{L})$ in the impoundment studied at Campo Verde, Mato Grosso, on the sampling dates.

\begin{tabular}{cccccc}
\hline Pesticide & Sample 01 & Sample 02 & Sample 03 & Sample 04 & Sample 05 \\
\hline Sampling date & Jul/05 & Ago/05 & Out/05 & Jan/06 & Abr/06 \\
DEA & ND & ND & ND & $\underline{0.09}$ & $\underline{0.2}$ \\
Atrazine & ND & ND & ND & $\underline{0.06}$ & $\underline{0.2}$ \\
Metolachlor & ND & ND & ND & $\underline{0.02}$ & ND \\
Chlorpyrifos & ND & ND & ND & $\underline{0.02}$ & ND \\
Endosulfan sulfate & $\underline{0.27}$ & $\underline{0.05}$ & ND & $\underline{0.1}$ & ND \\
Lambda cyhalothrin & $\underline{0.3}$ & ND & ND & ND & ND \\
Endrin & $\underline{0.23}$ & ND & ND & ND & ND \\
\hline
\end{tabular}

*ND: The pesticide was not detected.

tion, competition, and predation pressure, together with the physical and chemical conditions, including nutrient and food availability in the environment needed to maintain these activities.

The organisms serve as highly refined sensors of the environmental conditions and reflect the dynamics of an ecosystem better than any technological device [22]. It was observed that in July, the month during which the pesticides reach their highest concentrations, the algae become most abundant in the environments investigated (Figure 2).

This can be explained by the fact that the most concentrated pesticides found are inseticides with very little direct influence on algae. According to [17], the algae are known to be bioaccumulators of pesticides, especially the lipophilic ones that are adsorbed to their cellular membranes by virtue of the natural chemical properties of these cells. Some algae break down various organic compounds into simpler substances through the action of reductases, and also can utilize nitrogen after the pesticide breakdown.

In January, the opposite situation was observed (Figure 2); a great variety of pesticides were detected in the aquatic environment, and the algal populations were notably reduced. It is likely that the presence of the herbicides metolachlor, atrazine, and its metabolite DEA could be responsible for the reduction in the algal populations since they inhibit cellular growth [23].

Atrazine $\left(\mathrm{C}_{8} \mathrm{H}_{14} \mathrm{ClN}_{5}\right)$ is a triazine herbicide used to control pre- and post emergence broadleaf and grassy weeds on lawns, industrial lands, and among a variety of crops [24]. According to [25], the presence of the herbicide atrazine reduces the activity of the bacterial and algal populations. From this information, it can be inferred that the activities during this month were influenced by the presence of this pesticide.

Atrazine has been associated with diverse environmental problems, particularly contamination of soils and ground water. [17] reviewed the effects of various herbicides on algae and emphasized the complexity of the responses to these substances. For example, atrazine at concentrations in the aquatic media of less than $10 \mu \mathrm{g} / \mathrm{L}$ brought about a decrease in the algal biomass and, consequently, in its productivity. [26] encountered phytoplankton communities that were inhibited at concentrations of $20 \mu \mathrm{g} / \mathrm{L}$.

[27] reported that the inhibition of nitrogenase by atrazine is probably the first stage of interference with photosynthesis because it impedes nitrogen fixation. There are positive correlations between the concentrations of endosulfan ( $r=0.94 ; p=0.051)$, cyhalothrin $(r=0.96 ; p=0.037)$ and endrin $(r=0.96 ; p=0.037)$ and the biomass of desmids. Insecticides, such as endosulfan, inhibit the activity of ATPase, contributing considerably to the mortality of the biota, since ATP is of fundamental importance in the energy metabolism of all organisms. This form of general inactivation of the enzyme has lethal toxicological consequences [28].

Some of the most widely distributed xenobiotics are pesticides. More than 1000 pesticides are designated for use in the chemical control of agricultural pests. Most of them are classified primarily as herbicides, insecticides, and fungicides. Some of the chlorinated insectides are persistent and remain in the environment for more than ten years after they are applied [29].

At a United Nations conference in the year 2000, eight pesticides, including endrin, were designated as harm- 


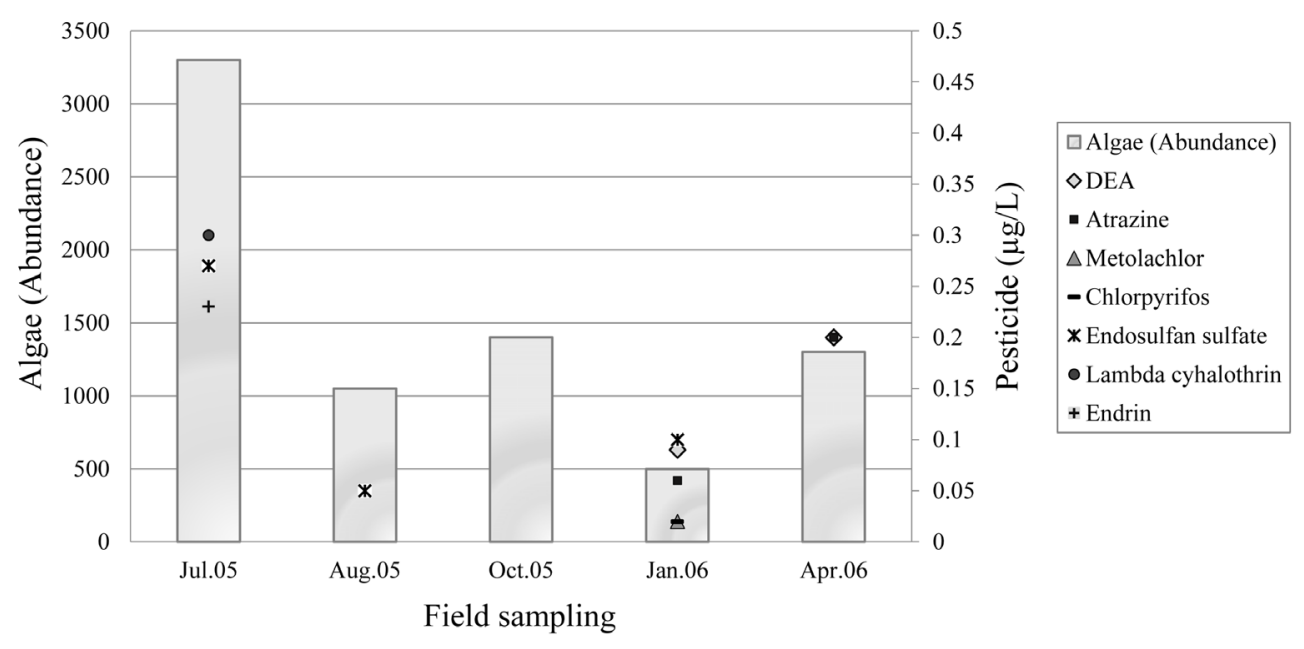

Figure 2. Relationship between abundance of algae in the family Desmidiaceae and concentrations of pesticides found in samples from the impoundment on the Pirassununga Ranch, Campo Verde, Mato Grosso.

ful to the environment and to health and prohibited in the signatory nations. During the period before the conference, the maximum concentration for endrin was set at $0.2 \mu \mathrm{g} / \mathrm{L}$, a level very difficult to monitor [30]. During the present study, an endrin concentration of $0.23 \mu \mathrm{g} / \mathrm{L}$ was recorded during the month of July.

Finally, the pesticides are toxic to living organisms and may also accumulate in microorganisms, plants, and animals, including human beings. Some are not easily eliminated from the organisms and can persist for decades. They are resistant to chemical, biological, and photolytic degradation, and can affect the health of human beings and ecosystems, even in small concentrations [31].

The continued overloading of surface waters in the agricultural region with pesticides necessitates a search for ecological criteria to adequately evaluate the capacity to detect and demonstrate the cargo of pollutants and the tolerance to their effects exhibited by lentic aquatic ecosystems.

The need to conduct analyses on other groups of aquatic organisms must be emphasized, so that a more extensive understanding of the complete functioning of the system and the interrelationships within it can be reached. To develop methods of bioindication, more fundamental studies should be conducted with the goal of determining those factors that can interfere with the system and thereby establish which species can serve as indicators of environmental alterations.

In this context, the taxonomic data provide additional confirmation of the results and, in addition, they demonstrate the relevance of taxonomic studies for biomonitoring. Finally, the ecotoxicological studies cannot be dissociated from taxonomic inventories, principally because of their value for determining the speed at which the harmful environmental impacts occur and induce the progressive loss of biodiversity.

\section{Conclusions}

The structure of the biotic communities in the ecosystems investigated is maintained in equilibrium by the forces of natural selection and the physical and chemical characteristics of the environment. This equilibrium may be affected when changes occur in these characteristics due to perturbations caused by the seasonal schedules of the farmers.

In addition to collecting samples from an impoundment in an agricultural region, located near one of the sources of the São Lourenço River on the Pirassununga Ranch in Campo Verde, Mato Grosso, the research focused on the microalga family, Desmidiaceae, and provided the first actual information on the specific effects of the pesticides on the algal flora of the region.

Pesticides were most frequently present in the samples during July, when algae were most abundant. Positive correlations between absolute algal abundance and the concentrations of endosulfan ( $r=0.94$ and $p=0.051$ ), cyhalotrin ( $r=0.96$ and $p=0.037)$, and endrin $(r=0.96$ and $p=0.037)$ were demonstrated.

In contrast, during the month of January, algae were least abundant, which is possibly related to the presence 
of atrazine $(r=-0.63$ and $p>0.05)$.

\section{Acknowledgements}

The authors are also grateful to FAPEMAT (Mato Grosso Research Support Agency) for supporting this study; Mr. Lorivaldo, the ranch owner, and the biologist Zaryf Araji Dahroug and Leonildo, a student of chemistry at UFMT, for performing pesticide analyses.

\section{References}

[1] Wiszniowski, J., Ter-Halle, A., Richard, C., Hitmi, A. and Ledoigt, G. (2009) Photodegradation Product of Sulcotrione and the Physiological Response of Maize (Zea mays) and White Mustard (Sinapis alba). Chemosphere, 74, 1224-1230. http://dx.doi.org/10.1016/j.chemosphere.2008.11.017

[2] Eichelberger, J.W. and Lichtenberg, J.J. (1971) Persistence of Pesticides in River Water. Environmental Science Technology, 5, 541-544. http://dx.doi.org/10.1021/es60053a002

[3] Ma, J., Wang, S., Wang, P., Ma, L. Chen, X. and Xu., R. (2006) Toxicity Assessment of 40 Herbicides to the Green Alga Raphidocelis subcapitata. Ecotoxicology and Environmental Safety, 63, 456-462. http://dx.doi.org/10.1016/j.ecoenv.2004.12.001

[4] Palma, P., Palma, V.L., Matos, C., Fernandes, R.M., Bohn, A., Soares, A.M.V.M. and Barbosa, I.R. (2009) Effects of Atrazine and Endosulfan Sulphate on the Ecdysteroid System of Daphnia magna. Chemosphere, 74, 676-681. http://dx.doi.org/10.1016/j.chemosphere.2008.10.021

[5] Scarlett, A. Donkin, P., Fileman, T.W., Evans, S.W. and Donkin, M.E. (1999) Risk Posed by the Antifouling Agent Irgarol 1051 to the Seagrass. Zostera marina. Aquatic Toxicology, 45, 159-170. http://dx.doi.org/10.1016/S0166-445X(98)00098-8

[6] Nyström, B., Becker-Van Slooten, K., Berard, A., Grandjean, D., Druart, J.C. and Leboulanger, C. (2002) Toxic Effects of Irgarol 1051 on Phytoplankton and Macrophytes in Lake Geneva. Water Research, 36, 2020-2028. http://dx.doi.org/10.1016/S0043-1354(01)00404-3

[7] Owen, R., Knap, A., Toaspern, M. and Karbery, K. (2002) Inhibition of Coral Photosynthesis by the Antifouling Herbicide Irgarol 1051. Marine Pollution Bulletin, 44, 623-632. http://dx.doi.org/10.1016/S0025-326X(01)00303-4

[8] Hall Jr., L.W., Giddings, J.M., Solomon, K.R. and Balcomb, R. (1999) An Ecological Risk Assessment for the Use of Irgarol 1051 as an Algaecide for Antifoulant Paints. Critical Reviews in Toxicology, 29, 367-437.

[9] Bérard, A., Dorigo, U., Mercier, I., Becker-Van Slooten, K., Grandjean, D. and Leboulanger. C. (2003) Comparison of the Ecotoxicological Impact of the Triazines Irgarol 1051 and Atrazine on Microalgal Cultures and Natural Microalgal Communities in Lake Geneva. Chemosphere, 53, 935-944.

[10] Parra, O.O. and Bicudo, C.E.M. (1995) Introdución a la Biologia y Sistemática de lãs Algas de Aguas Continentales. Gráfica Andes, Santiago, 269 p.

[11] Ricklefs, R.E. (2003) A economia da natureza. 5th Edition, Guanabara Koogan, Rio de Janeiro, 381-384. (In Portuguese)

[12] Laabs, V., Amelung, W., Pinto, A., Altstaedt, A. and Zech, W. (2000) Leaching and Degradation of Corn and Soybean Pesticides in an Oxisol of the Brazilian Cerrados. Chemosphere, 41, 1441-1449. http://dx.doi.org/10.1016/S0045-6535(99)00546-9

[13] Tortora, G.J., Funke, B.R. and Case, C.L. (2005) Microbiologia. 8th Edition, Artmed, Porto Alegre. (In Portuguese)

[14] Conselho Nacional Do Meio Ambiente. CONAMA. (National Council of Environment-Conselho Nacional do Meio Ambiente) (2005) Resolução n³57, de 17 de março de 2005. Dispõe sobre a classificação dos corpos de água e diretrizes ambientais para o seu enquadramento, bem como estabelece as condições e padrões de lançamento de efluentes, e dá outras providências. Diário Oficial da União, Brasília, 17 de março de 2005.

[15] Esteves, F.A. (1998) Fundamentos de Limnologia. 2nd Edition, Interciência, Rio de Janeiro, 602 p. (In Portuguese)

[16] Green, J. (1970) Freshwater Ecology in the Mato Grosso, Central Brazil I. The Conductivity of Some Natural Waters. Journal of Natural History, 4, 289-299. http://dx.doi.org/10.1080/00222937000770271

[17] Heckman, C.W. (1994) Pesticide Chemistry and Toxicity to Algae. Ergebnisse der Limnologie, Beiheft, 42, $205-234$.

[18] Hardoim, E.L. and Heckman, C.W. (1996) The Seasonal Succession of Biotic Communities in Wetlands of the Tropical Wet-and-Dry Climatic Zone: IV. The Free-Living Sarcodines and Ciliates of the Pantanal of Mato Grosso, Brazil. Internationale Revue der gesamten Hydrobiologie und Hydrographie, 81, 367-384. http://dx.doi.org/10.1002/iroh.19960810307 
[19] Moura, A.N., Wocyly-Dantas, Ê. and Bittencourt-Oliveira, M.C. (2007) Structure of the Phytoplankton in a Water Supply System in the State of Pernambuco-Brazil. Brazilian Archives of Biology and Technology, 50, 645-654. http://dx.doi.org/10.1590/S1516-89132007000400010

[20] Tundisi, J.G. and Matsumura-Tundisi, T. (2008) Limnologia. Oficina de Textos, São Paulo, 631 p.

[21] Dores, E.F.G.C. and De-Lamonica-Freire, E.M. (2001) Contaminação do ambiente aquático por pesticidas. estudo de caso: Águas usadas para consumo humano em Primavera do Leste, Mato Grosso-Análise preliminar. Química Nova, 24, 27-36. http://dx.doi.org/10.1590/S0100-40422001000100007

[22] Calijuri, M.C., Deberdt, G.L.B. and Minote, R.T. (1999) A produtividade primária pelo fitoplâncton na represa de Salto Grande (Americana-SP). In: Henry, R., Ed., Ecologia de reservatórios: Estrutura, função e aspectos sociais, FUNDIBIO, FAPESP, Botucatu, 111-148. (In Portuguese)

[23] Vallotton, N., Eggen, R.I.L., Escher, B.I., Krayenbühl, J. and Chèvre, N. (2008) Effect of Pulse Herbicidal Exposure on Scenedesmus vacuolatus: A Comparison of Two Photosystem II Inhibitors. Environmental Toxicology and Chemistry, 27, 1399-1407. http://dx.doi.org/10.1897/07-197.1

[24] Chiovarou, E.D. and Siewicki, T.C. (2008) Comparison of Storm Intensity and Application Timing on Modeled Transport and Fate of Six Contaminants. Science of the Total Environment, 389, 87-100. http://dx.doi.org/10.1016/j.scitotenv.2007.08.029

[25] Frighetto, R.T.S. (1997) Impacto Ambiental Decorrentes do Uso de pesticidas Agrícolas. In: Melo, I.S. and Azevedo, J.L., Eds., Microbiologia Ambiental, Embrapa-CNPMA, Jaguariúna, 415-438. (In Portuguese)

[26] DeNoyelles, F., Kettle, W.D. and Sinn, D.E. (1982) The Response of Plankton Communities in Experimental Ponds to Atrazine, the Most Heavily Used Pesticide in the United States. Ecology, 63, 1285-1293. http://dx.doi.org/10.2307/1938856

[27] Rohwer, F. and Fluckiger, W. (1979) Effect of Atrazine on Growth, Nitrogen Fixation, and Photosynthetic Rate of Anabaena Cylindrica. Angewandte Botanik, 53, 59-64.

[28] Yadwad, V.B., Kallapur, V.L. and Basalingappa, S. (1990) Inhibition of Gill $\mathrm{Na}^{+}$, $\mathrm{K}^{+}$-ATPase Activity in Dragonfly larva, Pantala flavesens, by Endosulfan. Bulletin of Environmental Contamination and Toxicology, 44, 585-589. http://dx.doi.org/10.1007/BF01700880

[29] Madigan, M.T., Martinko, J.M. and Parker, J. (1997) Brock Biology of Microorganisms. 8th Edition, Prentice Hall, Upper Saddle River, 166.

[30] Ritcher, C.A. and Azevedo Netto, J.M. (1991) Tratamento de água-tecnologia atualizada. Editora Edgard Blücher Ltda, São Paulo.

[31] Gomes, J.C. (2001) Poluição Industrial e Contaminação Humana no Brasil. ACPO-Associação de Combate ao POPs, Santos. (In Portuguese) http://www.acpo.org.br/inf_atualizadas/2001/pag_e_pdf/SEMINARIO_acpo.htm 
Scientific Research Publishing (SCIRP) is one of the largest Open Access journal publishers. It is currently publishing more than 200 open access, online, peer-reviewed journals covering a wide range of academic disciplines. SCIRP serves the worldwide academic communities and contributes to the progress and application of science with its publication.

Other selected journals from SCIRP are listed as below. Submit your manuscript to us via either submit@scirp.org or Online Submission Portal.
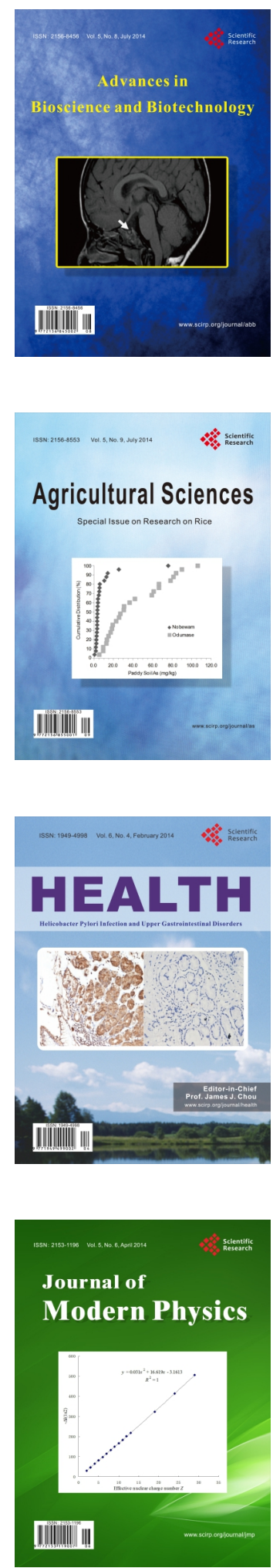
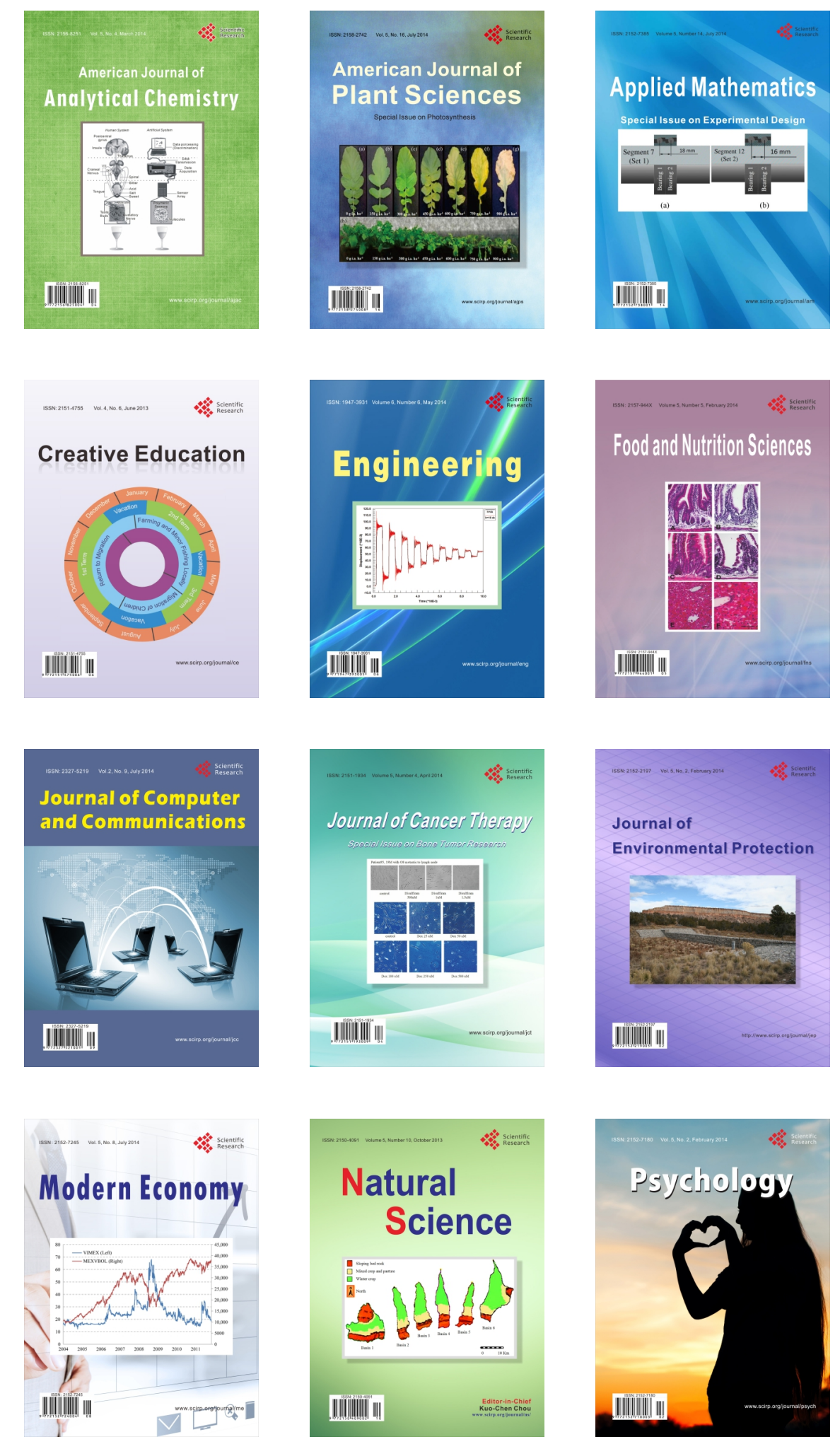